\title{
Morphological features of Camarosporium pini - the fungus associated to health state degradation in Austrian and Ponderosa pine
}

\author{
Helena Ivanová \\ Branch for Woody Plants Biology, Institute of Forest Ecology of the Slovak Academy of Sciences, Akademická \\ 2, 94901 Nitra, Slovak Republic
}

\begin{abstract}
Ivanoví, H., 2017. Morphological features of Camarosporium pini - the fungus associated to health state degradation in Austrian and Ponderosa pine. Folia Oecologica, 44: 54-57.

The subject of this study is escalated occurrence of the pathogenic fungus Camarosporium pini in the needle tissue of symptomatic trees $P$. nigra and $P$. ponderosa var. jeffreyi growing in urbanized settings and parks. $C$. pini induces severe infections and initiates a blight and premature loss of second-year foliage in pine trees. The fungus was identified microscopically and on base of morphological keys. The affected needles displayed a distinct bluish-grey necrotic band in the centre. On the surface of infected needles, there were formed pycnidia producing brown, oval conidia with three transversal and one or two vertical walls. Disease symptoms, some important characteristics in pure culture, and distinctive morphological features of C. pini associated to the health state degradation in Austrian and Ponderosa pine are described and compared. Cumulative effects of these stressful biotic and various abiotic factors may explain the current situation concerning the decline in the P. nigra and P. ponderosa var. jeffreyi in Slovakia.
\end{abstract}

Keywords

Camarosporium pini, Pinus nigra, P. ponderosa var. jeffreyi

\section{Introduction}

Needle and shoot blights in pines may be caused by a number of fungi. Within these, the fungus Camarosporium pini (Westend.) Sacc. (Dothidiomycetes), syn. Hendersonia pini Westend. induces a severe infection which may result in a significant growth reduction (Sutton, 1980; Farr and Rossman, 2014; Ivanoví, 2015). MinTER (1981) discusses Camarosporium pini as a common species, often associated with Pinus radiata D. Don. (Minter, 1977; Dennis, 1995), P. sylvestris L. (Francis, 1975; Minter et al., 1978; DennNIS, 1995; Ellis and Ellis, 1997; KaradžIĆ and MiLIJAŠEVIĆ, 2008; PASTIRČÁKOvá et al., 2014), P. nigra Arnold (Francis, 1975; Minter, 1979; Ivanoví and BERNADOVIČOVÁ, 2010; Ivanové, 2015) and $P$. contorta Dougl. (JAMES, 1984).

This micromycete parasitizes needles of trees debilitated by low temperatures in winters and by drought periods occurring from spring to summer seasons. The dry needles exhibit little back spots - pycnidia arranged linearly and parallel with the nervure (GROVE, 1937; Ivanová and Bernadovičová, 2010; Ivanová, 2015). Thus, combined effects of stressful abiotic factors predisposing trees health state together with enhanced occurrence of several pathogenic fungi traditionally known as secondary pathogens may explain the current situation in the pine tree decline in Slovakia.

The aim of this study was to investigate distribution, disease symptoms, some important characteristics in pure culture, growth and morphological attributes, distinctive morphological features in Camarosporium pini as a causative agent involved to different degrees in the health state degradation of Pinus nigra Arnold and P. ponderosa var. jeffreyi Peter \& Charles Lawson in urbanized settings and park.

\footnotetext{
*Corresponding author:

e-mail: helena.ivanova@savzv.sk
} 


\section{Materials and methods}

Fresh decaying plant materials were collected from localities in the Nitra town and in the Arborétum Mlyňany. Altogether 30 trees between 35-40 years were sampled. The experiments and morphometric measurements were carried out with implementing a widely accepted methodology (Ivanoví and Bernadovičová, 2010; IvaNoví, 2015). The identification of fungus was performed using morphological keys according to MINTER et al. (1978); LuO et al. (2010) or morphological studies in JAMES (1984) and Botella et al. (2010).

\section{Results and discussion}

Pinus nigra and Pinus ponderosa var. jeffreyi were disabled by the disease caused by the micromycetous fungus Camarosporium pini. This fungus initiates a blight and premature loss in the second-year foliage. The affected needles displayed a distinct bluish-grey necrotic band in the centre. A distinct black line often delimited the necrotic area from green tissues (JAMES, 1984). Pycnidia 180-300 (500) $\mu \mathrm{m}$ in diam. visible on the surface of infected needles were distinctly convex, subglobose, roundish or elongated and black. Brown and oval conidia with three transversal and one or two vertical walls were generally rounded at both ends, often slightly curved and coming out through a pycnidium subpapilliform pore (IVANOVÁ and BERNADOVIČOvÁ, 2010; IvANOVÁ, 2015).

Culture characters: Colonies on PDA of Pinus ponderosa var. jeffreyi reaching $3 \mathrm{~cm}$ diam. after one week at $24{ }^{\circ} \mathrm{C}$. This result is comparable with the data obtained during cultivation of Pinus nigra injured needles with colonies on PDA slow growing, 2.5-3 cm after one week at $24^{\circ} \mathrm{C}$. White mycelium gradually turned to dark grey (Fig. 1a). The reverse side was white, later becoming dark green to olive green from the centre (Ivanová and Bernadovičová, 2010; Ivanová, 2015). Our colonies obtained during cultivation of Pinus ponderosa var. jeffreyi injured needles formed dense mycelium, circular, with rough margin, white at first, later grey or dark grey, olive-green after 5 days in the centre of the colony, surrounded by white mycelium, flat on the surface, without aerial mycelium. The hyphae were septate branched, hyaline, the pycnidia up to $0.5 \mathrm{~mm}$ diam., black, erumpent, globose, separate, ostiolate, papillate, conidiophores short, simple, spherical, swelling the epidermis by pustules (Fig. 1b, c). The spores from pycnidia were produced within necrotic needles on short, hyaline conidiophores. The conidia were oblong, relatively large, dark, golden brown at maturity, ovoid to ellipsoid or elongate to fusoid, non-constricted at the septa, several-celled with 2-3 occasionally 4 transverse septa and 1-2 longitudinal septa $20(-22) 28-30 \times 10$ $(-12) 15 \mu \mathrm{m}$ in size, narrowly rounded at both ends, smooth walled (Fig. 1e). The mature conidia, apparently coated with a self-adhering material, were exuded through minute ostiolar openings situated by one on pycnidia penetrating the host epidermis. When wetted, the individual spores would separate and spread.

On the other hand, the conidia obtained during our cultivation of Pinus nigra injured needles were pale brown, thin-walled, with three or four transverse walls and one, sometimes two vertical walls, smooth fusiform to fusiform elliptical, straight, apex subobtuse, base truncate 20-22 × 6-8 $\mu \mathrm{m}$ (Fig. 1d) (Ivanová and BernadoviČové, 2010). Our results are morphologically similar to Camarosporium pini from Pinus contorta (JAMES, 1984) and to C. pini from P. sylvestris (ELLIS and ELLIS, 1997). The comparison of our results with the results of other authors is in Table 1.

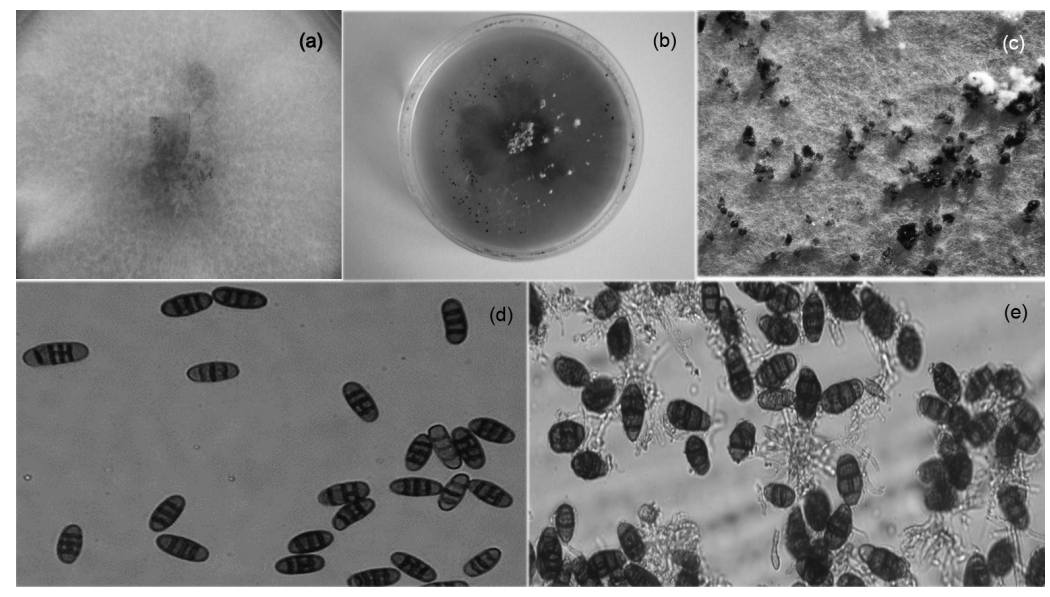

Fig. 1a. Mycelium of Pinus ponderosa var. jeffreyi; 1b, c. Pycnidia of the fungus Camarosporium pini; $1 \mathrm{~d}$. Conidia of C. pini on P. nigra; 1e. Conidia of C. pini on $P$. ponderosa var. jeffreyi.

Scale bars: $\mathrm{d}, \mathrm{e}=50 \mu \mathrm{m}$. 


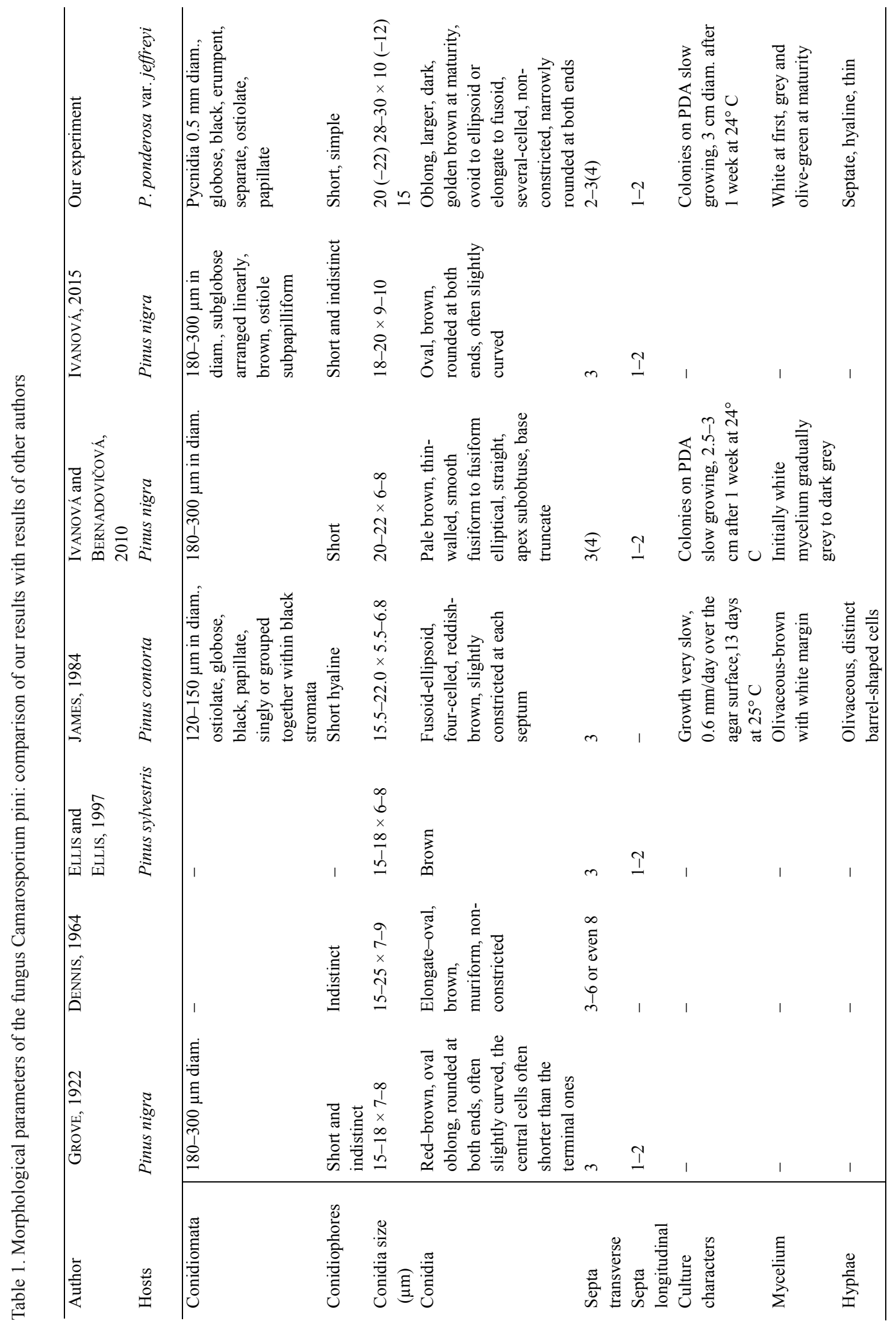




\section{Acknowledgement}

The author appreciates the support by the Scientific Grant Agency of Ministry of Education of the Slovak Republic and Slovak Academy of Sciences - VEGA, Projects No. 2/0069/14 and No. 2/0071/14.

\section{References}

Botella, L., Santamaria, O., Diez, J.J., 2010. Fungi associated with the decline of Pinus halepensis in Spain. Fungal Diversity, 40: 1-11.

DenNis, R.W.G., 1964. The fungi of the isle of Rhum. Kew Bulletin, 19: 77-127.

Dennis, R.W.G., 1995. Fungi of the South East England. Kew: Royal Botanic Gardens. 383 p.

Ellis, M.B., Ellis, J.P., 1997. Microfungi on land plants: an identification handbook. London \& Sydney: Croom Helm. 200 p.

FArR, D.F., Rossman, A.Y., 2014. Fungal databases. Systematic Mycology and Microbiology Laboratory, ARS, USDA. [cit. 2017-01-14]. http://nt.arsgrin.gov/fungaldatabases/

Francis, S.M., 1975. Anthostomella Sacc. (Part I). Mycological Papers, 139: 1-97.

Grove, W. B., 1922. New or noteworthy fungi. VIII. Journal of Botany, British and Foreign, 60: 81-86.

Grove, W. B., 1937. British stem and leaf fungi (Coelomycetes). Vol. 2. Cambridge: University Press. 407 p.

IvaNOvÁ, H., 2015. Fungi associated with a decline of Pinus nigra in urban greenery. Acta Fytotechnica et Zootechnica, 18 (2): 36-42.

Ivanová, H., Bernadovičová, S., 2010. Species diversity of microscopic fungi on Austrian pines growing in urban greenery of Nitra town. Folia Oecologica, 37: $168-180$.

James, R.L., 1984. Hendersonia blight of lodgepole pine in Idaho. Nursery Disease Notes, 9: 2-8.
KaRADŽıć, D., MiliJaŠEvić, T., 2008. The most important parasitic and saprophytic fungi in Austrian pine and Scots pine plantations in Serbia. Bulletin of the Faculty of Forestry, 97: 147-170.

Luo, J.T., Lin, Y.R., Shi, G.K., Hou, Ch.L., 2010. Lophodermium on needles of conifers from Yunnan Province, China. Mycological Progress, 9: 235-244.

MinTER, D.W., 1977. Lophodermium on pines with special reference to species occurring on Pinus sylvestris in North-East Scotland. PhD thesis. Aberdeen: University of Aberdeen, Department of Forestry. $401 \mathrm{p}$.

Minter, D.W., 1979. Pseudodiplodia cenangiicola sp. nov., a fungus on Cenangium ferruginosum. Karstenia, 19: 30-31.

Minter, D.W., 1981. Microfungi on needles, twigs and cones of pines in Czechoslovakia. Česká Mykologie, 35 (2): 90-101.

Minter, D.W., Staley, J.M., Millar, C.S., 1978. Four species of Lophodermium on Pinus sylvestris. Transactions of the British Mycological Society, 71 (2): 295-301.

Pastirčáková, K., Ivanová, H., PastirčÁK, M., 2014. Druhová diverzita húb na boroviciach (Pinus spp.) v mestskej a mimomestskej vegetácii [Species diversity of fungi on pines spp. in urban and suburban greenery]. In BARTA, M., Ferus, P. (eds). Dendrologické dni v Arboréte Mlyňany SAV 2014. Prostredie a vitalita drevín. Zborník referátov z konferencie. Vieska nad Žitavou: Arborétum Mlyňany SAV, p. $150-157$.

SutTon, B.C., 1980. The Coelomycetes: fungi imperfecti with pycnidia, acervuli and stromata. Kew: Commonwealth Mycological Institute. 496 p.

Received February 10, 2017 Accepted April 10, 2017 